\title{
Stres jako hrozba a současně výzva v profesi sociálního pracovníka ${ }^{1}$ Michal Kaczor
}

\begin{abstract}
Abstrakt
Hlavním cílem předkládaného příspěvku je představit stres jako jednu z dlouhodobě významných hrozeb 21. století, a to především v kontextu výkonu profese sociální práce. V návaznosti na to dále představit tzv. copingové strategie aneb způsoby, jakými se jedinci - sociální pracovníci - mohou se stresem vypořádávat. Na stres je v rámci článku pohlíženo jako na potenciální výzvu. V souvislosti s tímto je kladen dưraz na všímavost jakožto jeden z mnoha možných nástrojů převrácení hrozby stresu na výzvu, tedy efektivní práce se stresem. Nejsou opomenuty jak možnosti pěstování všímavosti v každodenním životě sociálních pracovníků, tak ani možná úskalí související s jejím praktikováním, na která je zapotřebí upozornit.
\end{abstract}

Klíčová slova: stres, osobnost, duševní hygiena, psychohygiena, mindfulness, všímavost, coping

\section{Úvod}

Předkládaný článek reaguje na aktuální a závažnou problematiku stresu v 21. století. Ten se stal v průběhu času fenoménem představujícím hrozbu pro mentální i tělesné zdraví jednotlivců (sociálních pracovníků), přičemž je takřka neustále skloňován, at’ už prostřednictvím médií, nejrůznějších literárních zdrojů anebo autorit. Pro příklad jmenujme jednu z těch hlavních - Ministerstvo práce a sociálních věcí České republiky. Hlavním cílem předkládaného př́spěvku je představit stres jako jednu z dlouhodobě významných hrozeb 21. století, a to především v kontextu vykonávání profese sociální práce jejím hnacím motorem - sociálními pracovníky; v návaznosti na to dále představit tzv. copingové strategie aneb způsoby, jakými se jedinci - sociální pracovníci - mohou se stresem vypořádávat. Na stres je v rámci článku pohlíženo jako na potenciální výzvu. V souvislosti s tímto je kladen důraz na všímavost jakožto jeden z mnoha možných nástrojů převrácení hrozby stresu na výzvu. Tedy nástroj, prostřednictvím kterého je možná efektivní práce se stresem, resp. zátěžemi, které jsou na sociálního pracovníka kladeny (nejen) v rámci výkonu jeho profese. Nejsou opomenuty jak možnosti pěstování všímavosti v každodenním životě sociálních pracovníků, tak ani možná úskalí související s jejím praktikováním, na která je zapotřebí upozornit a dále je analyzovat. 


\section{Stres v sociální práci 21 . století}

Stres, o kterém pojednává předkládaný článek, si ve své podstatě přitakává s tempem společnosti 21. století a úzce souvisí s jejími dobovými specifiky. Ne nadarmo tak bývá spojován s významnými hrozbami současné postmoderní společnosti. Sociální práce je pak zákonitě realizována v jejím dějišti a souvislostech. To, že je stres závažným problémem, který se nevyplácí podceňovat, můžeme odvozovat už z četných varování, která nás obklopují. Kupř́íladu, Světová zdravotnická organizace (WHO) varuje, že stres se stává největším zdravotním rizikem 21. století. ${ }^{2}$ Polínko do plamenné debaty přikládá i Ministerstvo práce a sociálních věcí ČR, které veřejně přiznalo, že: Stres je jedním $z$ nejzávažnějších problémi̊n, jimž dnes v oblasti bezpečnosti a zdraví př́i práci $v$ Evropě čelíme. Je mu vystaven téměr každý čtvrtý pracovník a ze studií je zrejejmé, že je také příčinou 50-60 \% všech zmeškaných pracovních dni. ${ }^{3}$ Naléhavost řešení pracovního stresu se v průběhu času nijak neumenšuje, ba naopak. V navrhované novele zákona č. 262/2006 Sb., zákoníku práce, je dokonce zakotvena ochrana před pracovním stresem. Paragraf 224 nově upozorňuje, že: Zaměstnavatelé jsou povinni vytvářet zaměstnancům pracovní podmínky, které umožňují bezpečný výkon práce, včetně předcházení riziku stresu spojeného s prací a riziku násilí a obtěžování na pracovišti, a v souladu se zvláštními právními předpisy zajištovat pro zaměstnance pracovnělékařské služby. ${ }^{4}$ Podle Nakonečného je stresující povaha současné doby doslova alarmující. V souvislosti s tímto můžeme jmenovat řadu faktorů, a to přímo souvisejících s praxí sociální práce - zejména strach ze sociálních nejistot, hrozba osamělosti, lhostejnost druhých lidí, neustálé spěchání, plnění povinností, neschopnost spočinout a mnoho dalších. ${ }^{5}$

Pojem „stres“ poprvé použil kanadský vědec Hans Selye, který jím označil stav, kdy musí organismus mobilizovat obranné či nápravné mechanismy. ${ }^{6}$ Obecně lze stres chápat jako duševní přetížení. To je prožíváno budto negativně - v takovém př́padě jde o tzv. distres (konfliktní vztahy mezi sociálními pracovníky na pracovišti, nepochopení klientů, rostoucí požadavky ze strany vedení apod.), anebo pozitivně - potom je označován jako tzv. eustres (časově náročná a komplikovaná práce s klientem, který se však postupně naučí své problémy řešit samostatně a je za pomoc vděčný apod.). ${ }^{7}$ Stres připravuje tělo ke konkrétní akci, tj. $\mathrm{k}$ útoku či útěku. Mobilizuje tedy vnitřní zdroje jedince $\mathrm{k}$ tomu, aby byl připraven útočit, anebo utíkat. To je na jednu stranu velmi účelné, ale na tu druhou to s sebou samozřejmě nese zákonitou daň, např́klad v podobě zhoršení svěžesti mysli, potíží s trávením, oslabení imunity nebo povrchního, neefektivního dýchání. Samoléčebné mechanismy těla jsou tímto „odsunuty“ do pozadí, stejně jako ušlechtilé city. V prŕípadě eustresu je tomu spíše naopak. Jako mírný stres zvyšuje bdělost, pozornost i motivaci, přičemž rozumové schopnosti se sebeovládáním jsou zachovány. ${ }^{8}$ Křivohlavý uvádí, že stres přichází tehdy, kdy se člověk dostává do zátěžové situace a odevšad na něj doléhá tlak. ${ }^{9}$ Vágnerová připomíná obě "tváŕe“ stresu. Tj. že stres lze chápat jednak jako stav nadměrného zatížení, či dokonce ohrožení, a jednak může člověka např. podněcovat k hledání řešení situace, resp. „cesty ven“, a tím mu pomáhat v rozvoji jeho kompetencí, včetně potřebné aktivizace a stimulace. ${ }^{10}$ Každá situace je

\footnotetext{
Srov. Kerstin KRASKA-LÜDECKE, Nejlepši techniky proti stresu, Praha: Grada, 2007, s. 45.

(c) MPSV, Před stresem v práci je třeba se chránit (on-line), dostupné na: https://www.mpsv.cz/cs/7893, citováno dne 12. 2. 2018.

Novela zákona č. 262/2006 Sb., zákoníku práce, ve znění pozdějších předpisů.

Srov. Milan NAKONEČNÝ, Psychologie: Přehled základních oborů, Praha: Triton, 2011, s. 622.

Srov. Vojtěch ČERNÝ - Kateřina GROFOVÁ, Relaxační techniky pro tělo, dech a mysl, Praha: Albatros Media, 2017 , s. 7.

Srov. Milan NAKONEČNÝ, Psychologie: Přehled základních oborů, Praha: Triton, 2011, s. 616-617.

Srov. Karel NEŠPOR, Duševní pružnost v každodenním životě, Praha: Portál, 2015, s. 17.

Srov. Jaro KŘIVOHLAVÝ, Psychologie zdraví, Praha: Portál, 2009, s. 170.

Srov. Marie VÁGNEROVÁ, Psychopatologie pro pomáhající profese, Praha: Portál, 2004, s. 50.
} 
specifická co se týče míry stresu, který pro jedince přináší. Totožná situace může být různými jednotlivci různě kognitivně zpracována, resp. interpretována. ${ }^{11}$

V sociální práci stres chápeme jako dynamický vztah mezi komplexem vnějších pracovních nároků nebo tlaků (četné návštěvy klientů, mnoho administrativních činností, permanentní komunikace s kolegy a klienty, dodržování legislativních parametrů ad.) a komplexem osobnostních dispozic. Právě osobnostní dispozice hrají zásadní roli v tom, zda je sociální pracovník (ne)schopen zvládat nároky či tlaky adaptivním způsobem. ${ }^{12}$ Představme si situaci, kdy je sociální pracovník dlouhodobě vystaven komplexu různých okolností. Pravidelně navštěvuje klienty $\mathrm{v}$ jejich domovech a provádí sociální šetření. Přitom má však nedostatek času, jelikož počet klientů přesahuje jeho kapacitu. Reálně tak hrozí, že nebude zvládat další, neméně nutné povinnosti. Dále zpracovává dokumentaci z realizovaných sociálních šetření a zabezpečuje další nevyhnutelnou administrativu v rámci své práce. Do kanceláře $\mathrm{k}$ němu chodí různí klienti, žadatelé o služby, z nichž řada jedná arogantním způsobem a s jakousi pohotovostí $\mathrm{k}$ agresivnímu jednání. Při práci může být navíc občas postaven i před různá dilemata. A neopomínejme ani potenciální osobní problémy, včetně problémů ve vlastní rodině, konfliktů na pracovišti - at už s kolegy, nebo s nadřízenými apod. Pro jednoho sociálního pracovníka toto mohou být díky jeho specifickým osobnostním dispozicím relativně dobře zvladatelné stresory. Pro jiného sociálního pracovníka může být tento dlouhodobý stres v důsledku jeho specifických osobnostních dispozic jen ztěží zvladatelný. Relativně snadno se potom stres může stát jistým činitelem v rozvoji duševních onemocnění, jako třeba deprese, syndrom vyhoření ad. V odborných pramenech není v současné době žádných pochybností o tom, že dlouhodobě působící pracovní stres se u sociálních pracovníků může výrazně promítat $\mathrm{v}$ různých směrech. Např́klad ve smyslu snižování kvality a efektivity práce, klesající spokojenosti klientů s poskytovanými službami, „nabourávání kultury a efektivity pracovních organizací apod. Neopomínejme ani širokou škálu nežádoucích fenoménů, $\mathrm{k}$ nimž může dlouhodobý stres vést. Takovými mohou být např́klad rutinizace práce, zvýšená pracovní absence, maladaptační obtíže včetně zmiňovaného syndromu vyhoření, deprese či jiných zdravotních následků dlouhodobého stresu. ${ }^{13}$

Společně s hrozbou stresu však přicházejí zároveň otázky, jak jej zvládat, resp. pomocí jakých strategií (nejen) sociální pracovníci zacházejí či mohou zacházet se stresem. O tom pojednává následující kapitola, která se věnuje tomuto okruhu, tj. tzv. copingovým strategiím.

\section{Coping aneb způisoby vyrovnávání se se stresem}

Pro vyrovnávání se se zátěží, resp. čelení stresu je často používán vžitý termín coping, který je odvozen od řeckého slova „kolaphus“ čili rána protivníkovi v boxu. Za onoho boxera můžeme pro potřeby tohoto článku považovat sociálního pracovníka, který se dostal do zátěžové situace a vypořádává se s ní protiútokem. Proces zvládání zátěžových situací bývá označován také různými jinými termíny, např. stress management či moderování stresu. Souhrnně jde o př́ístupy, resp. způsoby chování vedoucími ke snižování zátěže/stresu, který v jejím důsledku vzniká. ${ }^{14}$ Snyder v obecnosti uvádí, že coping je určitou odpovědí zaměřenou na zmenšení fyzické, emocionální

11 Srov. NAKONEČNÝ, Psychologie..., s. 622.

12 Srov. Zdeněk MLČÁK, Potenciální zdroje stresu v sociální práci a jejich zvládání, Sociální práce / Sociálna práca 3/2005, s. 125.

13 Srov. MLČÁK, Potenciální..., s. 125.

14 Srov. Jaro KŘIVOHLAVÝ, Psychologie zdraví, Praha: Portál, 2009, s. 69. 
a psychické zátěže, která mimo jiné souvisí se stresujícími životními událostmi a každodenními potî̌̌emi. ${ }^{15}$ Paulík dále uvádí, že coping je ustáleným výrazem pro aktivní a vědomý způsob zvládání stresu. ${ }^{16} \mathrm{~S}$ tím souvisí fakt, že jedinec se na základě zhodnocení dané situace a posouzení vlastních možností zaměří na cíl, jehož výsledkem by mělo být dosažení pozitivní změny a tolerance, a to při zachování psychické rovnováhy a pozitivního sebeobrazu - mělo by pak dojít ke zlepšení celkové bilance. ${ }^{17}$ Jedinec může vzniklou zátěž řešit v podstatě dvěma nejčastějšími způsoby, a to bud' pasivní rezistencí, anebo aktivním jednáním směřujícím $\mathrm{k}$ vyřešení situace, přičemž se musí sám rozhodnout, jaké řešení je to nejvhodnější. ${ }^{18}$ Aktivní jednání se tedy zakládá na tom, že situaci a $\mathrm{z}$ ní vzniklou zátěž lze řešit a jedinec je $\mathrm{v}$ tomto směru připraven učinit aktivní kroky. Jako př́klad lze zmínit situaci, kdy vedení organizace na sociálního pracovníka klade zátěž neustálým přidáváním nových povinností, které však již přesahují jeho kapacitu. Sociální pracovník tak ve vhodnou chvíli iniciuje schůzi s vedením, kde nastíní téma pracovního přetěžování a všichni společně začnou aktivně jednat o tom, jak vzniklou situaci řešit ke spokojenosti sociálního pracovníka, tj. směrem ke snižování jeho pracovního stresu. Pasivní rezistence obvykle vychází ze situace, kterou není možné nikterak změnit. Se vzniklou zátěží je v tomto smyslu zapotřebí nakládat tak, aby byla zachována optimální psychická rovnováha a minimalizovány nežádoucí důsledky. Př́kladem může být situace, kdy sociálnímu pracovníkovi - streetworkerovi - zemře jeho drogově závislý klient v důsledku předávkování. Přestože sociální pracovník vyvíjel mnoho úsilí, aby klientovi od jeho závislosti pomohl, jeho práce se nyní může jevit jako „zbytečná“. Namístě tedy je, aby se s touto situací smířil a interpretoval ji v zájmu zachování své mentální rovnováhy, např̀. slovy „Jednal jsem nejlépe, jak jsem dovedl a moje práce měla i přes toto smysl.“

Důležitým termínem v oblasti zvládání zátěže je resilience, kterou lze do češtiny přeložit jako nezdolnost, houževnatost, odolnost - tj. jistou schopnost zvládnout situaci, kdy je člověk konfrontován se značně nepř́znivými okolnostmi. ${ }^{19}$ Můžeme se setkat též s termínem hardiness, v překladu osobní tvrdost, jejíž stupeň je důležitý při zvládání zátěžových situací. Ukazuje se, že lidé, kteří disponují vyššími hodnotami v dimenzi osobní tvrdosti, mají mnohonásobné výhody. Častěji používají účinné a aktivnějši strategie řešení problémů, tedy aktivně jednají, namísto toho, aby zůstali v pasivní rezistenci, jsou tělesně i psychicky zdravější apod. Významná je též koherence jedince, jednak ve smyslu sociální pospolitosti (soudržnost skupiny lidí, do které člověk patří - např. rodina, partner, přátelé ad.), a jednak ve smyslu vnitřní jednoty, resp. skloubenosti osobnosti člověka - tzv. pevného charakteru. Pakliže člověk disponuje touto pevnou vnitřní jednotou a žije v soudržné společenské skupině, je lépe vybaven $\mathrm{k}$ tomu, aby odolával zátěžovým situacím. ${ }^{20}$

Se základními a inspirativními efektivními strategiemi zvládání zátěže, resp. stresu se můžeme seznámit např́klad u Feldmana:

- odvrácení hrozby výzvou - pokud například sociální pracovník ví, že mu činí problém moderovat konfliktní situace s klienty, mưže tomu čelit tím, že se přihlásí na kurz asertivního jednání;

- zmenšení hrozby situace - pokud se začne vzniklá situace vymykat kontrole člověka, je

15 Srov. Charles R. SNYDER, Coping: The Psychology of What Works, Oxford: Oxford University Press, 1999 , s. 5.

16 Srov. Karel PAULÍK, Psychologie lidské odolnosti, Praha: Grada, 2017, s. 118.

17 Srov. Marie VÁGNEROVÁ, Psychopatologie pro pomáhající profese, Praha: Portál, 2004, s. 57.

18 Srov. Eva BEDRNOVÁ a kol., Duševní hygiena a sebeřizení pro vysokoškoláky a mladé manažery, Praha: Fortuna, 1999 , s. 68.

19 Srov. Iva ŠOLCOVÁ, Vývoj resilience v dětství a dospělosti, Praha: Grada, 2009, s. 11.

20 Srov. Jitka MACHOVÁ a kol., Výchova ke zdraví, Praha: Grada, 2009, s. 133. 
vhodné upravit její vlastní hodnocení, a tak změnit svůj postoj vůči ní - například když je sociální pracovník zavalen povinnostmi a připadá mu, že práci nestihne vykonat včas, může si říct, že situace je pouze dočasná a zvládnul i daleko více nepříjemné okamžiky, než je zrovna tento - smyslem je najít v každé negativní situaci něco dobrého;

- změna vlastních cílů - pokud vznikne nekontrolovatelná situace, je dobré si vytyčit nový cíl - např́íklad sociální pracovník, který v rámci vysokého pracovního nasazení podlehl syndromu vyhoření, si může po rekonvalescenci v rámci jeho prevence upravit pracovní návyky vhodným zpo̊sobem, aby se to v budoucnu již neopakovalo;

- fyzická akce - nežádoucí fyzické důsledky stresu může člověk překonávat pomocí fyzické aktivity, např. pokud je sociální pracovník vystaven dennímu vysokému psychickému napětí ve svém zaměstnání, může po pracovní době provozovat různé aktivity jako běh, florbal, jógu, cyklistiku a mnohé další, což napomáhá eliminovat zvýšený krevní tlak a další negativní důsledky zátěže;

- preventivní př́íprava na stres - tzv. „očkování proti stresu“ informacemi o stresorech i antistresových programech - sociální pracovník může navštívit různé semináře, kurzy a jiné programy věnující se redukci stresu, potažmo jeho lepšímu snášení. ${ }^{21}$

Dostupných strategií, kterými se jedinec může inspirovat a zakomponovat je do svého každodenního života, je celá řada. Různí autoři představují různé způsoby, jak lze přistupovat k zátěžím, stresu a negativním emocím. Prezentovat pohledy dalších autorů je bohužel již nad kapacitu tohoto článku. Co se týče samotné volby konkrétních strategií práce se stresem, konečné rozhodnutí je pouze na sociálním pracovníkovi. Právě to, že má možnost si vybrat strategii takovou, která u něj funguje a přináší mu benefity na úrovni psychické odolnosti, je podnětem k tomu, aby aktivně odvrátil hrozbu a vnímal stresové situace jako výzvu $\mathbf{k}$ celkové změně. Sociální pracovník si tedy může zcela podle svého uvážení zvolit copingovou strategii, která mu nejvíce vyhovuje. Přitom mu může velmi pomoci reflexe toho, jaká forma práce se stresem pro něj byla v minulosti, s ohledem na jeho osobnostní nastavení, efektivní. A jaká naopak nikoli. Nutno dodat, že sociální pracovníci jsou „motorem“, čili nepostradatelným nástrojem efektivního pomáhajícího procesu. ${ }^{22}$ Je tedy zapotřebí věnovat pozornost takovým prostředkům, které rozvíjejí jejich osobnost a udržují duševní i tělesné zdraví v rovnováze. Právě jejich prostřednictvím je možné převrátit hrozbu stresu na výzvu, a to především díky skutečnosti, že v nich lze nalézt efektivní nástroj $\mathrm{k}$ práci se stresem, jehož naléhavost je postupně redukována. Jedním z takových je dále pojednávaná všímavost, která sociálnímu pracovníkovi přináší mnoho benefitů - jak bude blíže specifikováno.

\section{Všímavost jako možný nástroj převrácení hrozby stresu na výzvu}

Jak bylo výše nastíněno, strategií, se kterými se lze s hrozbou stresu vyrovnávat a aktivně mu tímto čelit, je nespočet. S ohledem na omezenou kapacitu článku není v silách autora se zabývat byt’ třeba jen menší částí takových strategií. Bude tedy představena jedna konkrétní, která je v současné době na vzestupu a těší se velké oblibě. Tou je všímavost (čili mindfulness), o které budou podrobněji pojednávat následující řádky př́íspěvku. Všímavost bývá v definicích představována

21 Robert FELDMAN, Efektivní strategie zvládání stresu. In Milan NAKONEČNÝ, Psychologie: Přehled základních oborů, Praha: Triton, 2011, s. 624.

22 Srov. Andrej MÁTEL - Milan SCHAVEL - Pavel MÜHLPACHR - Tibor ROMAN, Aplikovaná etika v sociální práci, Brno: Institut mezioborových studií, 2010, s. 93-94; srov. Karel KOPŘIVA, Lidský vztah jako součást profese, Praha: Portál, 2006, s. 94. 
jako „vědomí o jednotlivých momentech“ či „zaměřování pozornosti na přítomný okamžik ve specifickém módu - tj. bez posuzování a hodnocení. Svou povahou všímavost podporuje pozornost ke každému pohybu, dechu, cítění a myšlení. ${ }^{23}$ Obecně mủžeme říci, že: Všímavost je uvědomělost, utvářená pozorností neprètržitým a konkrétním zpưsobem: záměrně, v př́tomném okamžiku, objektivně (nekriticky). Je jedním ze zpi̊sobư meditace, pokud meditaci chápeme jako: 1. systematické usměrňování naši pozornosti a energie, 2. tím ovlivňování a přeměna našich zkušeností, 3. v prủběhu rozpoznávání celého spektra lidství a 4. naše vztahy s dalšími lidmi a světem. ${ }^{24}$ Hassonová konkretizuje, co je jádrem tohoto př́stupu: Mindfulness může člověku pomoci přehlušit ubijejíci proud myšlenek, které se mu neustále honí hlavou. ${ }^{25}$ Dále se zmiňuje o tom, že si můžeme snadno představit mnoho životních okamžiků, ve kterých se staneme všímavými - naplno prožívajícími konkrétní momenty. To například, když jsme „ponořeni“ do hraní stolní hry nebo luštění křřžovky, do poutavého dějství v oblíbené knize či filmu nebo do psaní zajímavého dopisu. ${ }^{26}$ Právě takovéto všímavé prožívání konkrétních činností napomáhá jedinci oprostit se od navyklého automatizovaného jednání. A naopak, přibližuje jej vnitřnímu klidu a stabilitě, které mu pomáhá kultivovat i posilovat. ${ }^{27}$

Nyní se dostáváme k neopomenutelným souvislostem všímavosti (mindfulness) a sociální práce, které mohou být motivací a jistým východiskem toho, aby se (nejenom) sociální pracovníci, podléhající stresu, začali o všímavost coby efektivní nástroj více zajímat. Například pro její značný potenciál převrácení hrozby stresu na výzvu - tj. krok kupředu k efektivnímu zacházení se stresory působícími na každodenní život sociálního pracovníka. A to jak na ten osobní, tak i na profesní. Pro konkrétní představu jmenujme třeba následující exemplární př́nosy související s praktikováním všímavosti. Zlepšení komunikace a srozumitelnosti, účinnější řešení problémů a zvládání konfliktů, zvýšení efektivity práce a koncentrace, rovněž zlepšení vztahů s kolegy na pracovišti, posilování tvůrčího myšlení i rovnováhy a odolnosti na pracovišti a v domácím prostředí a konečně podpora psychické a fyzické pohody (čili wellbeingu), snižování hladiny stresu a naopak zvyšování energetické hladiny. ${ }^{28}$ Navíc, sociální pracovník praktikující všímavost si může být díky ní více vědom těch věcí, které jsou na jeho pracovišti dysfunkční a zaujmout $\mathrm{k}$ nim patřičný kritický postoj. ${ }^{29}$

Najdeme rovněž řadu styčných ploch, které sociální práci se všímavostí propojují. Pro obě je zásadní hodnotou jedincova individuální, žitá zkušenost $\mathrm{v}$ kontextu jeho jedinečného života. Všímavost, stejně jako sociální práce, ve svém přístupu zdůrazňuje péči o sebe a sebe-akceptaci. Stejně tak nehodnotící prrístup je charakteristickým znakem jak pro všímavost, tak pro sociální práci. $^{30}$ Péče o sebe je důležitým aspektem v praxi sociálního pracovníka. Ten může všímavost

23 Srov. Robyn LYNN - Jo MENSINGA, Social Workers' Narratives of Integrating Mindfulness into Practice, Journal of Social Work Practice 3/2015, s. 255-256.

24 Jon KABAT-ZINN, Mindfulness for Beginners: Reclaiming the Present Moment - and Your Life, Colorado: Sounds True, 2012 , s. 1.

25 Gill HASSON, Technika mindfulness: Jak se vyvarovat duševní prokrastinace prostřednictvím všímavosti a bdělé pozornosti, Praha: Grada, 2015, s. 28.

26 Srov. Gill HASSON, Mindfulness: Be Mindful. Live in the Moment, UK: John Wiley \& Sons, 2013.

27 Srov. Michael SINCLAIR - Josie SEYDEL, Všímavost: Cesta pro zklidnění mysli pro ty, co nestíhají, Praha: Grada, 2015, s. 26.

28 Srov. (c) SSSC News, Bringing Mindfulness to Social Work (on-line), dostupné na: http://ssscnews.uk.com/2014/11/27/bringingmindfulness-workplace-social-work, citováno dne 1. 7. 2017; srov. Louise GRANT - Gail KINMAN, Developing Resilience for Social Work Practice, UK: Palgrave, 2014.

29 Srov. Jim ROGERS - Lucy BRIGHT - Helen DAVIES, Social Work with Adults, UK: Sage Publications, 2015.

30 Srov. Francis J. TURNER, Social Work Treatment: Interlocking Theoretical Approaches, Oxford: Oxford University Press, 2017, s. 335336. 
mnohostranně využít - k redukování stresu, navození pocitu klidu či zvýšení uvědomělosti atd. ${ }^{31}$ Právě mnohostranné využití dává sociálním pracovníkům svobodu, jak s potenciálem všímavosti naloží. Puddicombe toto přirovnává k jízdě na kole. Člověku nejprve někdo ukáže, jak na kole jezdit, aniž by mu stanovoval, jak tuto dovednost konkrétně využívat. Teprve postupem času, když si člověk jízdu na kole řádně osvojí a naučí se ji, si sám stanovuje, k jakému účelu ji bude využívat (zda k dojíždění do zaměstnání, realizaci duševní hygieny atd.). ${ }^{32}$ Všímavost je navíc kvalitou, která může pomoci sociálnímu pracovníkovi přistupovat ke všem situacím týkajícím se jeho praxe s jasností, soustředěností a soucitem. ${ }^{33}$ Pro sociální práci je rovněž zajímavé, že pokud chceme trvale a vědomě, s bdělou pozorností jednat s jiným člověkem (klientem), v první řadě je $\mathrm{k}$ tomu zapotřebí rozvinout všímavost $\mathrm{k}$ sobě samému. ${ }^{34} \mathrm{Na}$ tomto místě je vhodné připomenout, že výsledkům různých výzkumů zaměřených na všímavost se věnuje samostatná kapitola článku Všimavost (mindfulness) jako potenciální nástroj rozvoje osobnosti sociálního pracovníka. ${ }^{35}$

\section{I přes optimistický charakter poznatků souvisejících s účinky všímavosti na jedince je zapo-} třebí mít na paměti taktéž potenciální negativní důsledky, potažmo rizika. Vzhledem $\mathrm{k}$ nedostatku relevantních vědeckých poznatků nelze o rizicích zatím mnoho vyvozovat. Jako př́klad možných nežádoucích následků lze uvést rozvoj tzv. „kontemplativní disociace“, tedy absence propojenosti myšlenek, emocí a tělesných pocitů. Ta podle odborníků vzniká právě skrze permanentní pozornost $\mathrm{k}$ tělu, $\mathrm{v}$ jejímž důsledku se jedinec praktikující všímavost dotkne minulých fyzických či psychických traumat, která doposud nebyla adekvátně zpracována. To může, mimo jiné, způsobit nežádoucí emocionální dysbalanci, kterou je následně komplikované uzdravovat. ${ }^{36}$ Taktéž byla zpracována sumarizace studií, které udávaly nepříznivé vedlejší účinky u praktikujících frekventantů různých druhů meditací (včetně mindfulness meditace). Mezi tyto patří např. depersonalizace (pocit odpojení od duševních procesů nebo těla), psychóza (ztráta kontaktu s realitou) s bludy, halucinacemi a neorganizovaným projevem, pocity úzkosti, zvýšené riziko záchvatů, ztráta chuti k jídlu nebo nespavost. Sám výzkumný tým však zmiňuje, že doposud nebyly rozpracovány postupy screeningu praktikujících účastníků, bezpečnostní mantinely výzkumů či standardy pro výcvik výzkumných pracovníků. ${ }^{37}$ Podobné výzkumy je tedy zapotřebí realizovat i nadále, a tím přispívat k většímu objasnění reálných rizik spojených s praktikováním všímavosti.

Následující a poslední kapitola pojednává o samotné realizaci potenciálu výzvy, tedy jaké možnosti mají sociální pracovníci z hlediska rozvíjení a udržování všímavosti. K dispozici je totiž celá řada ucelených a strukturovaných programů, mezi kterými je zapotřebí vybrat si ten vhodný. Tj. takový, který svým zaměřením a konkrétním obsahem koresponduje s očekáváními jeho frekventanta - sociálního pracovníka.

31 Srov. Aneesha KELLY - Ifeoma OKOLO, Mindfulness Meditation as a Self-Care Practice in Social Work, in: Master of Social Work Clinical Research Papers, Minnesota: School of Social Work, 2016, s. 2.

32 Srov. Andy PUDDICOMBE, Uklidte si v hlavě: stačí 10 minut denně, Praha: Grada, 2016, s. 20.

33 Srov. Edward R. CANDA - Leola D. FURMAN, Spiritual Diversity in Social Work Practice: The Heart of Helping, Oxford: Oxford University Press, 2010, s. 362.

34 Gabriele ROSSBACH, Síla přítomného okamžiku: 15 meditačních cvičení pro plnější a radostnější život, Praha: Grada, 2014 , s. 28.

35 Srov. Michal KACZOR, Všímavost (mindfulness) jako potenciální nástroj rozvoje osobnosti sociálního pracovníka, Caritas et Veritas 2/2017, s. 40-50.

36 Srov. David TRELEAVEN, Meditation, Trauma, and Contemplative Dissociation, Somatics: Magazine-Journal of the Mind/Body Arts and Sciences 2/2010, s. 20-22.

37 Srov. Kathleen B. LUSTYK - Neharika CHAWLA - Roger S. NOLAN - Alan MARLATT, Mindfulness Meditation Research: Issues of Participant Screening, Safety Procedures, and Researcher Training, Advances 1/2009, s. 20-30. 


\section{Realizace potenciálu výzvy - rozvíjení a udržování všímavosti}

Pokud se sociální pracovník rozhodne využívat všímavost jako efektivní nástroj pro práci se stresem, je rovněž důležité, aby zvolil takový př́stup, který je mu blízký. Hovoříme především o ucelených a strukturovaných programech založených na pěstování všímavosti, kterých je celá řada. Určitým „zlatým standardem“ je osmitýdenní program, mezinárodně nazývaný MBSR (Mindfulness-Based Stress Reduction) čili program založený na snižování stresu, vycházející z mindfulness principů, který sestavil Jon Kabat-Zinn na univerzitě v Massachusetts. Mimo to ale existuje stále rostoucí počet jiných programů, př́mo odvozených z toho základního - MBSR. Pro představu lze uvést následující: MBCT (Mindfulness-Based Cognitive Therapy) - tedy program kognitivní terapie založené na všímavosti, MBRP (Mindfulness-Based Relapse Prevention), čili program prevence relapsu postavený na základech všímavosti a nakonec třeba MBRE (Mindfulness-Based Relationship Enhancement) - tj. program zlepšování partnerských vztahů prostřednictvím všímavosti. ${ }^{38}$ Pro účely tohoto článku přiblížíme dva hojně zastoupené a obvykle realizované programy, tedy MBSR a MBCT. Ty se v průběhu času staly známým standardem. Jsou navíc dlouhodobě předmětem různých výzkumů a v tomto ohledu jsou empiricky ověřené. Každý z obou programů má odlišný původ, a to zejména ve smyslu cílové skupiny a teoretické inspirace. MBSR i MBCT však mají společný formát. Oba rozvíjejí plejádu dovedností podporujících všímavost člověka. ${ }^{39}$ Další neoddiskutovatelnou výhodou je, že sociální pracovník je může v př́ípadě potřeby využívat obousměrně. Tedy jak při svém vlastním rozvoji osobnosti, tak rovněž v intervencích se svými klienty. Všímavost se dá dobře použít u široké škály klientů, tak například u těch, kteří trpí depresemi, úzkostmi, u těch, kteří jsou v permanentním stresu a napětí, či mají nízké sebevědomí apod.

MBSR (Mindfulness-Based Stress Reduction) - je osmitýdenním kurzem, který se obvykle skládá ze dvouapůlhodinových (či alternativně, tř́ihodinových) setkání v každém jednotlivém týdnu. Mezi šestým a sedmým týdnem je pak zpravidla uspořádáno celodenní setkání, založené na tiché praxi všímavosti. Samožrejmostí je každodenní domácí praxe. Program MBSR je určen všem, kteří mají zájem se učit efektivně zacházet se stresem prostřednictvím svých vlastních zdrojů a tím komplexně zvýšit kvalitu života. ${ }^{40}$ Program byl založen v sedmdesátých letech minulého století ve Spojených státech amerických Jonem Kabatem-Zinnem. Používal se zejména v klinickém prostředí, a to u jedinců se širokou škálou diagnóz - od přemíry stresu, přes závislosti na návykových látkách, až po chronickou bolest. ${ }^{41}$ Program je založen hlavně na sebepozorování a zvládání stresu, a to za použití formálních technik snižujících stres, jako např. jóga. Účastníci jsou vedeni $\mathrm{k}$ tomu, aby si byli více vědomi stresorů v každodenních činnostech. Do průběhu programu je aplikována rovněž vzájemná diskuze mezi účastníky. Ta má sloužit především k podpoře individuálního učení. ${ }^{42}$

MBCT (Mindfulness-Based Cognitive Therapy) - vytvořili jej Zindal Segal, Mark Williams a John Teasdale $\mathrm{v} 90$. letech minulého století, a to se záměrem pomoci lidem $\mathrm{s}$ depresí (v klinickém prostředí). Program MBCT spojuje všímavost s prvky kognitivně behaviorální terapie, a je

38 Srov. Ed HALliWELL, Mindfulness: How to Live Well by Paying Attention, USA: Hay House, 2015.

39 Srov. GERNER - SIEGEL - FULTON, Mindfulness..., s. 124; srov. Jenny WANG - Juliet ADAMS, Bringing Mindfulness to Your Workplace, USA: Association for Talent Development, 2016, s. 8.

40 Srov. Linda LEHRHAUPT - Petra MEIBERT, Mindfulness Based Stress Reduction: The MBSR Program for Enhancing Health and Vitality, Novato: New World Library, 2017, s. 3.

41 Srov. Shamash ALIDINA, Mindfulness for Dummies, USA: John Wiley \& Sons, 2015, s. 243.

42 Srov. Malcolm PAYNE, Modern Social Work Theory, Oxford: Oxford University Press, 2016, s. 167. 
tedy, na rozdíl od MBSR, více zaměřen na pomoc lidem zjistit, jak efektivně pracovat s jejich mys-

lí. ${ }^{43} \mathrm{~S}$ programem MBSR nicméně úzce souvisí a sdílí s ním většinu jeho obsahu. Hlavní rozdíl mezi nimi je v tom, že MBSR se soustředí na mentální nesnáze (jako např. stres, úzkost, strach) obecně a MBCT se více soustředí na to, jak člověk uvažuje, resp. myslí. Jako velmi efektivní se ukazuje v práci se stresem, úzkostmi, depresemi a podobnými problémy psychického původu. Program MBCT totiž umně pracuje s tzv. módem autopilota, který u spousty jedinců, trpících jmenovanými problémy, hraje důležitou roli. Autopilot totiž člověka uvádí do ryze automatizovaných a navyklých reakcí, a tím jej udržuje v zažitých vzorcích jednání. Ty však s ohledem na problémy psychického původu mohou být velmi nežádoucí a tvořit jakýsi jedincův „začarovaný kruh“ opakujících se problémů, kterým navíc vlivem automatizovaného jednání řádně neporozuměl. ${ }^{44}$

Nutno dodat, že v České republice jsou pro veřejnost standardně dostupné kurzy MBSR pod vedením kvalifikovaného lektora, Mgr. Jaroslava Chýleho (CFM Qualified MBSR Teacher). Ten získal kvalifikaci přímo v Centru pro mindfulness na lékařské fakultě Univerzity v Massachusetts. ${ }^{45}$ Mimo výše uvedené organizované a strukturované způsoby trénování všímavosti (tj. mimo různé programy, jakými jsou např. přiblížené MBSR a MBCT) má však sociální pracovník možnost zvolit vlastní cestu. To třeba v případě, kdy mu nevyhovuje práce v kolektivu, která je nedílnou součástí organizovaných kurzů, nebo pokud je pro něj platba za realizaci programu neúnosným nákladem, a v dalších podobných situacích. Existuje totiž spousta odborných publikací, jako napr. dílo Jona Kabata-Zinna „Život samá pohroma: Jak čelit stresu, nemoci a bolesti pomocí moudrosti těla a mysli“46, které jsou konstruovány jako určitý manuál, resp. alternativa tréninku všímavosti pro samouky. V každém případě, zásadním faktorem v životě sociálního pracovníka je „neusnout na vavř́nech" a aktivně jednat. Pasivita jej totiž může snadno uvrhnout do zdánlivě bezvýchodné situace, kdy relativně snadno podlehne dojmu, že se zátěží, resp. stresem nelze nic dělat a stane se jeho obětí. To však zdaleka není pravda, jak se snažil tento článek nastínit. Fenomén všímavosti je v souvislosti s vykonáváním sociální práce nadále nutno zkoumat a přinášet nové poznatky, kterých je v tuto chvíli nedostatečné množství. I to může sociálním pracovníkům velmi pomoci v tom, aby ve všímavosti nalezli stabilní oporu a využívali ji jako nástroj k převrácení hrozby stresu na výzvu k celkové změně.

\section{Závěr}

Článek pojednával o stresu jakožto hrozbě a zároveň výzvě pro sociální pracovníky a jejich profesi. V první kapitole byl komplexně představen stres, zejména prostřednictvím jeho pojetí jednotlivými autory. Nebyla opomenuta ani významná společenská varování před stresem 21. století, se kterými přišlo Ministerstvo práce a sociálních věcí či Světová zdravotnická organizace. Na to pak plynule navázala kapitola druhá, jež přiblížila problematiku copingu, tj. způsobů, jakými se jedinec (sociální pracovník) vyrovnává se stresem. Přiblíženy byly rovněž vztahující se termíny, tj. resilience, osobní tvrdost nebo koherence. Podstatným faktem jest, že sociální pracovníci mají

43 Srov. Patrizia COLLARD, Mindfulness Based Cognitive Therapy For Dummies, USA: John Wiley \& Sons 2013, s. 10.

44 Richard SEARS, Building Competence in Mindfulness-Based Cognitive Therapy: Transcripts and Insights for Working With Stress, Anxiety, Depression, and Other Problems, New York: Routledge, 2015, s. 1.

45 Pozn.: Více informací lze najít na oficiálních webových stránkách: http://www.mbsr.cz/.

46 Srov. Jon KABAT-ZINN, Život samá pohroma: Jak čelit stresu, nemoci a bolesti pomocí moudrosti těla a mysli, Brno: Jan Melvil Publishing, 2016. 
možnost vybrat si takovou strategii, která je vzhledem k jejich potřebám a osobnostnímu nastavení efektivní a přináší jim benefity (mj.) na úrovni psychické odolnosti. Právě taková strategie je podnětem $\mathrm{k}$ tomu, aby aktivně odvrátili hrozbu a vnímali stresové situace jako výzvu k celkové změně. $\mathrm{V}$ další kapitole byla představena všímavost právě jako jeden $\mathrm{z}$ možných nástrojů, resp. potenciálních efektivních strategií práce se stresem. Takový dává sociálnímu pracovníkovi prríležitost převrátit hrozbu stresu/zátěže na výzvu. Výzvou je zde myšleno především to, že sociální pracovník začne prostřednictvím tohoto nástroje efektivně řešit vzniklé zátěže, a tím zároveň efektivně odbourávat stres. Nakonec bylo praktikování všímavosti blíže rozvedeno v poslední kapitole, která pojednávala o samotné realizaci potenciálu výzvy, tedy o způsobech, jakými může sociální pracovník rozvíjet a udržovat všímavost. Těmi jsou různé dostupné programy vycházející z filosofie mindfulness. Článek se soustředil na dva nejčastější a empiricky ověřené, tedy na MBSR a MBCT. I nadále je však potřeba se fenoménu všímavosti (mindfulness) v sociální práci věnovat a přinášet nové empirické poznatky, kterých je v současné době málo - tím spíše v prostředí české sociální práce.

\section{Kontakt}

\section{Mgr. Michal Kaczor}

Jihočeská univerzita v Českých Budějovicích

Teologická fakulta, Katedra etiky, psychologie a charitativní práce

Kněžská 8, 37001 České Budějovice

info@michalkaczor.cz 